Abstracta Iranica Abstracta Iranica

Revue bibliographique pour le domaine irano-aryen

Volume 27 | 2006

Comptes rendus des publications de 2004

\title{
Rumi. Paris, Médicis-Entrelacs, 2004, 279 p. [Sagesses éternelles]
}

Ève Feuillebois-Piérunek

\section{Q OpenEdition}

1 Journals

Édition électronique

URL : http://journals.openedition.org/abstractairanica/6374

DOI : 10.4000/abstractairanica.6374

ISSN : 1961-960X

\section{Éditeur :}

CNRS (UMR 7528 Mondes iraniens et indiens), Éditions de l'IFRI

\section{Édition imprimée}

Date de publication : 15 mai 2006

ISSN : 0240-8910

\section{Référence électronique}

Ėve Feuillebois-Piérunek, «Rumi. Paris, Médicis-Entrelacs, 2004, 279 p. [Sagesses éternelles] », Abstracta Iranica [En ligne], Volume 27 | 2006, document 300, mis en ligne le 02 janvier 2007, consulté le 25 septembre 2020. URL : http://journals.openedition.org/abstractairanica/6374 ; DOI : https:// doi.org/10.4000/abstractairanica.6374

Ce document a été généré automatiquement le 25 septembre 2020.

Tous droits réservés 


\title{
Rumi. Paris, Médicis-Entrelacs, 2004, 279 p. [Sagesses éternelles]
}

\author{
Ève Feuillebois-Piérunek
}

Cet ouvrage de bonne vulgarisation, écrit dans un style enthousiasmant, se compose classiquement de trois parties. La première, la plus longue, est une biographie détaillée de Rumi, où l'accent est mis sur le cheminement spirituel. La seconde présente les grandes lignes de la pensée du poète à travers la description de ses œuvres. La troisième est une anthologie des principaux écrits de Rumi en référence aux points évoqués dans les deux parties précédentes. La traduction est élégante et plus fidèle à l'esprit qu'à la forme. Une chronologie et une bibliographie sélective complètent l'ensemble.

\section{INDEX}

Thèmes : 11.1.1. Littérature persane classique

\section{AUTEURS}

ÈVE FEUILLEBOIS-PIÉRUNEK

Sorbonne Nouvelle - Paris III 